\title{
Effects of Steel Composition on the Surface Reactivities of Steel Sheets*
}

\author{
By Shoji SHIMADA, ** Shigeyoshi MAEDA** ana \\ Takatoshi EGAWA**
}

\section{Synopsis}

The effects of elements, manganese, sulfur and oxygen in steel sheets on rusting tendency and the properties of the phosphate coatings formed thereon have been studied by using pure iron and low carbon rimmed steel sheets to which controlled amounts of these elements had been added.

The rate of rusting of base sheets is determined by the " pack rust test" and the humidity cabinet test, and the resistance to blistering of the laquered phosphated sheets is examined by the salt spray test.

The chemical reactivity of the steel surface is affected considerably by the presence of these elements; the rate of rusting increases substantially with increase of precipitated $\mathrm{MnS}$ and $\mathrm{MnO}$, and the ability to form protective phosphate films increases with increase of total manganese content.

The above results can be ascribed to the property of $\mathrm{MnS}$ to accelerate iron dissolution anodically in both rusting and phosphating, while manganese in solid solution serves as a cathodic dipolarizer in phosphating. Manganese oxide has a beneficial effect forming protective phosphate films since its precipitation during hot rolling changes the equilibrium of manganese and sulfur in austenite and therefore favours precipitation of fine $\mathrm{MnS}$ during subsequent annealing.

\section{Introduction}

Various surface scratches (defect), rusting, or phosphate treatment are important problems related to surface properties of cold-rolled steel sheets, which necessitate careful consideration from the viewpoint of their manufactures and uses. Because they are so easily rusted when exposed to the atmosphere, coldrolled steel sheets are not usually used as they are, but with protective metallic coating or painting (commonly following the phosphate treatment). Accordingly, their surface reactivity, including rust formation and phosphate reactivity, is not less important than their mechanical properties. However, very few papers have been presented on the study of the effects of their manufacturing conditions and composition from this viewpoint. In contrast to this, extensive studies have been made on the effects on the compositions and the structure of steel with regard to general corrosion in aqueous solutions. For instance, Hoar and Havenhand, ${ }^{1)}$ and Williams and Komp, ${ }^{2)}$ published reports on the effects of copper and sulfur, Cleary and Greene, ${ }^{3)}$ on the behavior of cementite, and Fluoulis and Uhlig, ${ }^{4)}$ on the effects of steel structure and several elements added to steel in small quantities. Also, many papers have been issued since the development of weathering steels on the effects of steel composition, mainly in connection with the rust layer formed on the surface of steel.5) But, considerable attention has not been paid to the effect of aforesaid factors on the initial rust formation and the phosphate film formation on the surface of steel. This study is aimed to solve this problem. When the rusting is limited to a pinpoint rusting before the steel surface is covered with a continuous rust layer, it is considered that the dissolution rate of iron at the weak points (defects) of the oxide film of steel surface controls the corrosion rate. Also, the pretreatment given to a steel sheet exerts a great influence on the formation of phosphate film. It is presumed that structural factors of the steel sheet have an influence on its surface reactivity. For instance, Tomashov pointed out that the corrosion reaction on a metal surface adhering a thin film of water is anodic control because diffusion of oxygen takes place readily. ${ }^{6}$ ) The authors, also investigated the influence of manufacturing conditions, e.g., annealing and cold-rolling of the steel sheet, on phosphate reactivity, and showed mainly the effect of the texture of base steel. At the same time, the authors suggested that the composition of steel also had a great influence. ${ }^{7)}$ In the cold-rolled steel sheets, contents of carbon, nitrogen and other elements are controlled chiefly in connection with their mechanical properties. These sheets further contain manganese, sulfur and oxygen that cannot be eliminated for technical reasons, aluminum and silicon as deoxidizers, and a variety of tramp elements such as nickel, copper and the like. It is still not known what influence these elements show on the surface reactivity of steel. In this study, the influence of manganese, sulfur and oxygen in steel on the surface reactivity has primarily been investigated.

\section{Experimental Procedure}

\section{Preparation of Specimens}

\section{Steels with Different Oxygen Contents}

Ten kilograms each of 7 types of electrolytic-ironbase steel and 8 types of low-carbon-rimmed steel (SP)-base, 15 types in total containing different amounts of oxygen, were prepared using a vacuum melting furnace. The low-oxygen types were deoxidized with carbon, while the high-oxygen types were oxidized with ferric oxide. Chemical compositions of the steels are shown in Table 1.

These steels were made into cold-rolled steel sheets (annealed) through the following processes:

Vacuum melting $\rightarrow$ hot-rolling (kept at $1250^{\circ} \mathrm{C}$ for $30 \mathrm{~min}$, and finished at $910^{\circ} \mathrm{C}$ to $2.3 \mathrm{~mm}$ thick) $\rightarrow$ picklling (dipped for $30 \mathrm{sec}$ in a $5 \%$ aqueous solution of hydrochloric acid at $\left.85^{\circ} \mathrm{C}\right) \rightarrow$ cold rolling (bright finished to $0.80 \mathrm{~mm}$ thick) $\rightarrow$ electrolytic

* Originally published in Tetsu-to-Hagané, 61 (1975), 2639, in Japanese. English version received December 11, 1975.

** Process Technology R \& D Laboratories, Nippon Steel Corp., Edamitsu, Yawata-Higashi-ku, Kitakyushu 805. 
cleaning $\rightarrow$ annealing ( $\mathrm{HNX}$ gas, $\mathrm{DP}<-20^{\circ} \mathrm{C}$, at $700^{\circ} \mathrm{C}$ for $2 \mathrm{hr}$ ).

\section{Mn-S-O Balanced Steels}

Taking into consideration the results of the specimens prepared under II.1.1, 12 types of steels containing different balanced amounts of manganese, sulfur and oxygen were made according to the same process, by use of a vacuum melting furnace. The aimed contents of the individual elements were as follows.

Manganese: 3 levels $0.09,0.02$ and $0.03 \%$

Sulfur: $\quad 2$ levels 0.007 and $0.034 \%$

Oxygen: 2 levels 0.006 and $0.035 \%$

Therefore, $3 \times 2 \times 2=12$ types.

Carbon: Fixed at less than $0.01 \%$

Chemical compositions of the 12 types of steels are listed in Table 2.

\section{Steels with Different Amounts of Sulfur Precipitated}

In order to check the effect of the precipitation of sulfur in steel on the surface reactivity, 2 types of hotrolled strip (of rimmed steel) as shown in Table 3 were selected, and made into specimens with different thermal histories (one being quenched and the other cooled slowly after hot rolling) under the following conditions.

Hot-rolled strip $\rightarrow$ heat treatment* $\rightarrow$ pickling $\rightarrow$ cold-rolling (to $0.8 \mathrm{~mm}$ thick) $\rightarrow$ electrolytic cleaning $\rightarrow$ rusting test $\rightarrow$ annealing $\rightarrow$ rusting test

(HNX gas, $\mathrm{DP}-20^{\circ} \mathrm{C}, 700^{\circ} \mathrm{C} \times 2 \mathrm{hr}$ )

* Heat treating conditions

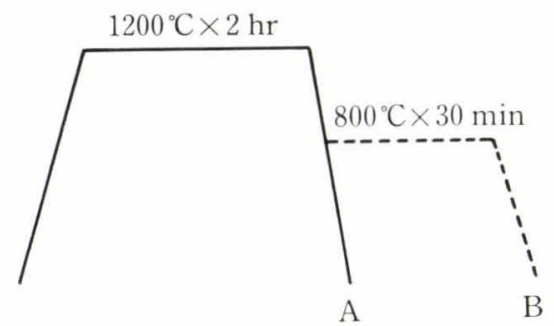

A : Water quenched from $1200^{\circ} \mathrm{C}$

B: Cooled slowly from $1200^{\circ}$ to $800^{\circ} \mathrm{C}$, and then water quenched

Table 1. Chemical compositions of samples (wt \%)

\begin{tabular}{|c|c|c|c|c|c|c|c|c|c|c|}
\hline & Sample & C & $\mathrm{Si}$ & $\mathrm{Mn}$ & $\mathrm{P}$ & $\mathrm{S}$ & sol. N & insol. $\mathrm{N}$ & $\mathrm{Cu}$ & $\mathrm{O}$ \\
\hline \multirow{6}{*}{ Pure iron base } & $P-1$ & 0.004 & 0.0012 & 0.01 & 0.004 & 0.006 & 0.0025 & 0.0015 & 0.005 & 0.009 \\
\hline & $\mathrm{P}-2$ & 0.003 & 0.0012 & 0.01 & 0.004 & 0.006 & 0.0028 & 0.0014 & 0.004 & 0.010 \\
\hline & $\mathrm{P}-3$ & 0.003 & 0.0012 & 0.01 & 0.004 & 0.007 & 0.0027 & 0.0008 & 0.004 & 0.021 \\
\hline & $P-4$ & 0.003 & 0.0013 & 0.01 & 0.005 & 0.007 & 0.0031 & 0.0012 & 0.006 & 0.046 \\
\hline & $\mathrm{P}-5$ & 0.003 & 0.0012 & 0.01 & 0.005 & 0.007 & 0.0030 & 0.0010 & 0.004 & 0.048 \\
\hline & $\mathrm{P}-7$ & 0.004 & 0.0013 & 0.01 & 0.003 & 0.006 & 0.0030 & 0.0011 & 0.005 & 0.068 \\
\hline \multirow{8}{*}{$\begin{array}{l}\text { Low carbon rimmed } \\
\text { steel base }\end{array}$} & $\mathrm{R}-1$ & 0.005 & 0.015 & 0.30 & 0.006 & 0.028 & 0.0026 & $\operatorname{tr}$ & 0.050 & 0.010 \\
\hline & $\mathrm{R}-2$ & 0.006 & 0.015 & 0.31 & 0.004 & 0.025 & 0.0026 & $\mathrm{tr}$ & 0.050 & 0.010 \\
\hline & $\mathrm{R}-3$ & 0.004 & 0.015 & 0.31 & 0.004 & 0.026 & 0.0028 & 0.0014 & 0.047 & 0.016 \\
\hline & $R-4$ & 0.006 & 0.015 & 0.31 & 0.004 & 0.026 & 0.0032 & tr. & 0.047 & 0.017 \\
\hline & $R-5$ & 0.006 & 0.010 & 0.29 & 0.004 & 0.026 & 0.0033 & 0.0006 & 0.045 & 0.030 \\
\hline & $\mathrm{R}-6$ & 0.005 & 0.017 & 0.30 & 0.004 & 0.026 & 0.0031 & 0.0006 & 0.050 & 0.033 \\
\hline & $\mathrm{R}-7$ & 0.006 & 0.010 & 0.28 & 0.005 & 0.029 & 0.0030 & 0.0010 & 0.040 & 0.041 \\
\hline & $\mathrm{R}-8$ & 0.007 & 0.012 & 0.29 & 0.005 & 0.029 & 0.0030 & 0.0011 & 0.040 & 0.045 \\
\hline
\end{tabular}

Table 2. Chemical compositions of steels with balanced amounts of manganese, sulfur and oxygen (wt \%)

\begin{tabular}{|c|c|c|c|c|c|c|c|c|c|c|}
\hline & C & $\mathrm{Mn}$ & $\mathrm{Si}$ & $\mathrm{P}$ & $\mathrm{S}$ & $\mathrm{O}$ & sol. $\mathrm{N}$ & insol. $\mathrm{N}$ & {$[\mathrm{Mn}]^{*}$} & Mn precip.** \\
\hline$M-1$ & 0.010 & 0.09 & 0.025 & 0.002 & 0.007 & 0.006 & 0.0028 & 0.0004 & 0.057 & 0.047 \\
\hline M- 2 & 0.008 & 0.09 & 0.020 & 0.002 & 0.034 & 0.006 & 0.0029 & 0.0002 & 0.011 & 0.079 \\
\hline$M-3$ & 0.010 & 0.09 & 0.025 & 0.002 & 0.008 & 0.034 & 0.0050 & 0.0002 & $*-0.027$ & 0.090 \\
\hline$M-4$ & 0.006 & 0.09 & 0.022 & 0.002 & 0.033 & 0.041 & 0.0038 & 0.0002 & -0.108 & 0.090 \\
\hline$M-5$ & 0.008 & 0.21 & 0.022 & 0.002 & 0.008 & 0.016 & 0.0024 & 0.0004 & 0.141 & 0.059 \\
\hline$M-6$ & 0.004 & 0.20 & 0.022 & 0.002 & 0.036 & 0.014 & 0.0030 & 0.0006 & 0.090 & 0.110 \\
\hline$M-7$ & 0.008 & 0.20 & 0.021 & 0.002 & 0.007 & 0.034 & 0.0030 & 0.0010 & 0.071 & 0.129 \\
\hline$M-8$ & 0.006 & 0.20 & 0.022 & 0.002 & 0.036 & 0.031 & 0.0028 & 0.0010 & 0.031 & 0.196 \\
\hline$M-9$ & 0.009 & 0.32 & 0.010 & 0.001 & 0.006 & 0.013 & 0.0020 & 0.0004 & 0.265 & 0.055 \\
\hline M-10 & 0.007 & 0.33 & 0.008 & 0.001 & 0.031 & 0.015 & 0.0020 & 0.0004 & 0.226 & 0.104 \\
\hline M-11 & 0.006 & 0.29 & 0.002 & 0.001 & 0.008 & 0.033 & 0.0021 & 0.0006 & 0.156 & 0.134 \\
\hline
\end{tabular}

* $\mathrm{Mn}$ in solution $=$ total $\mathrm{Mn} \%-\left(\frac{55}{32} \times \mathrm{S} \%+\frac{55}{16} \times \mathrm{O} \%\right)$

** $\mathrm{Mn}$ precip. $=$ total $\mathrm{Mn} \%-\mathrm{Mn}$ in solution $\%$ 


\section{Steels with Different Sulfur and Carbon Contents}

Specimens of 4 types of low and ultra-low-carbon steels, containing different amounts of sulfur and carbon as shown in Table 4 were also prepared.

\section{Evaluation of Surface Reactivity}

The surface reactivities of the steels were evaluated by rust formation and phosphate film on their surfaces.

\section{Rusting Test}

Two kinds of accelerated rusting tests, employing different conditions, were performed to check rust formation.

(1) Humidity Cabinet Test

In a thermo-hydrostat (JAN-H-792), which was kept at $49^{\circ} \mathrm{C} \pm 1{ }^{\circ} \mathrm{C}$ in temperature and more than $98 \%$ in relative humidity, the specimen $(10 \mathrm{~cm}$ by $10 \mathrm{~cm}$ in size) was allowed to rust while being suspended from the suspension ring and rotated. Rust was formed on the surface covered with a considerably thick film of water ${ }^{8)}$ (approximately $30 \mu$ ), and the degree of rusting was expressed by the ratio of the rusting area observed with the naked eye.

(2) Pack Rusting Test

In a thermo-hydrostat kept at $40^{\circ} \mathrm{C}$ and $90 \%$ relative humidity, several to several tens of specimens $(10 \mathrm{~cm}$ by $10 \mathrm{~cm})$, piled up and tightly bound together, were allowed to rust. The thickness of water film condensed on specimen's surfaces was very thin owing to the action of capillary condensation averaging not more than $0.001 \mu$.

\section{Phosphate Film Forming Reaction}

Steel sheets are commonly used after being treated with phosphate and painted. Corrosion resistance after painting is largely dependent upon the phosphate film formed under the paint. The denser the phosphate film, the greater will be the corrosion resistance. As revealed in our previous paper, ${ }^{7)}$ the denseness of film formed depends on the degree of chemical activities of the surface of the base steel. In the previous paper, phosphate film formation was evaluated by the number of nuclei precipitated out.

In the present experiment, corrosion resistance of steel painted on phosphated sheet has been measured. Namely, the estimation of corrosion resistance is based on the previous paper that corrosion resistance of

Table 3. Chemical compositions of SP steels (wt\%)

\begin{tabular}{c|ccccccc} 
& C & Si & Mn & P & S & Cu & O \\
\hline SP-A & 0.04 & 0.005 & 0.29 & 0.014 & 0.026 & 0.045 & 0.058 \\
SP-B & 0.04 & 0.007 & 0.29 & 0.014 & 0.016 & 0.047 & 0.031
\end{tabular}

painted steel increases with an increase in the activity of phosphate reaction (which results in the precipitation of more phosphate nuclei and the formation of a denser film). Phosphate treatment and painting conditions employed were as follows:

Phosphate treatment: Bonderite \#100 (made by Nihon Parkerizing Co., Ltd.; zinc phosphate type) at $60^{\circ} \mathrm{C}$ was sprayed for $2 \mathrm{~min}$.

Painting: Paint of amino-alkyd type, $20 \mu$, was sprayed on and baked at $160^{\circ} \mathrm{C}$ for $20 \mathrm{~min}$.

Corrosion resistance was determined by measuring the percentage of the blistered area after ten day exposure in salt spray tester.

\section{Experimental Results}

\section{Oxygen Contents and Rusting}

The results of the rusting test on the annealed steel specimens containing different amounts of oxygen (of the pure-iron-base and SP-base types) are shown in Figs. 1 and 2. As seen from these figures, oxygen content showed quite different effects on rusting between pure-iron-base type and the SP-base type. For the SP-base type, the amount of rust formed increased in approximate proportion to the amount of oxygen contained. Whereas, the pure-iron-base type was scarcely affected by oxygen on rusting. Since oxygen in steel substantially exists as non-metallic inclusions (such as $\mathrm{MnO}$ and $\mathrm{FeO}$ ), it is firstly presumed that these oxides had some influence on the formation of rust. In Fig. 3, oxygen content is plotted against cleanliness of steel expressed in terms of non-metallic inclusion content. The cleanliness decreased (that is,

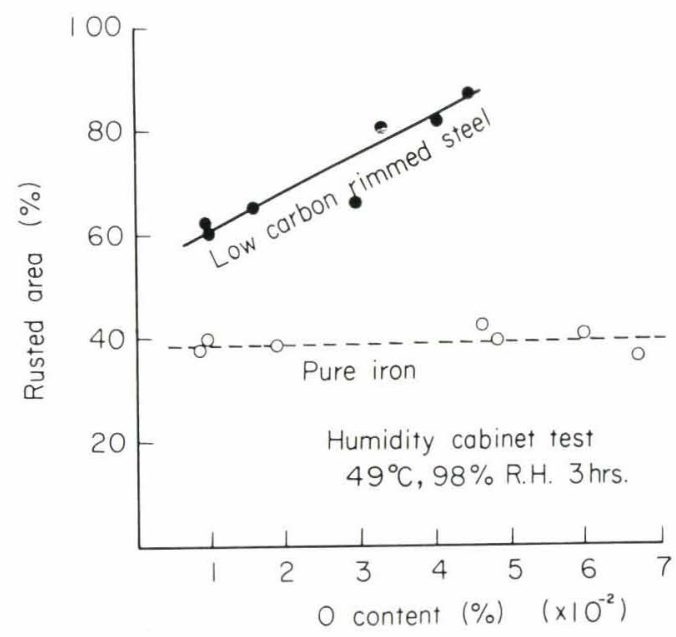

Fig. 1. Effect of oxygen content on rusting

Table 4. Chemical compositions of low carbon and ultra low canbon steels (wt \%)

\begin{tabular}{|c|c|c|c|c|c|c|c|c|}
\hline & & $\mathrm{C}$ & $\mathrm{Si}$ & $\mathrm{Mn}$ & $\mathrm{P}$ & $\mathrm{S}$ & $\mathrm{Cu}$ & $\mathrm{MnS}^{*}$ \\
\hline Low C nor. Mn & $\mathrm{S}-1$ & 0.04 & 0.01 & 0.33 & 0.012 & 0.013 & 0.02 & 0.0223 \\
\hline Low C low Mn & $\mathrm{S}-2$ & 0.04 & & 0.10 & 0.005 & 0.005 & & 0.0086 \\
\hline Ultra low $\mathrm{C}$ nor. $\mathrm{Mn}$ & $\mathrm{S}-3$ & 0.005 & 0.02 & 0.40 & 0.012 & 0.012 & 0.03 & 0.0210 \\
\hline Ultra low $\mathrm{C}$ nor. $\mathrm{Mn}$ & $S-4$ & 0.005 & & 0.10 & 0.008 & 0.007 & & 0.0120 \\
\hline
\end{tabular}

* Calculated from S content 


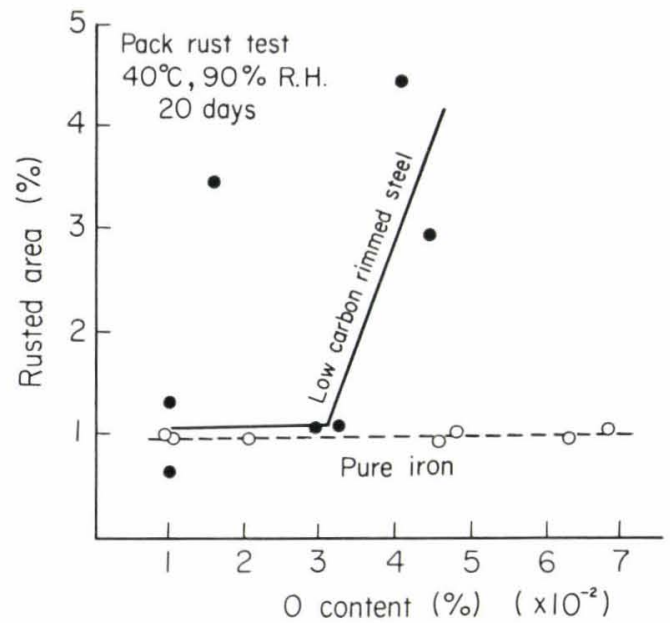

Fig. 2. Effect of oxygen content on rusting

the percentage of non-metallic inclusions increased) with increase in the oxygen content, both with the pure-iron-base and SP-base types. (Naturally, the percentage of non-metallic inclusions is somewhat higher for the SP-base type than for the pure-ironbase type, because the former contains more impurities such as sulfur.) Since the amount of inclusions (of oxide type) increases with oxygen content in the pure-iron-base type too, it does not seem that the amount of such inclusions is the main cause of rusting, rather their quality (for instance, chemical composition and form) seems to be responsible.

Here, the rusted areas of the pure-iron-base and SP-type steels with the same oxygen content cannot be compared simply, since their copper contents, which are known to have an influence on rusting, differ from each other. Accordingly, the specimens with the same copper content were used in the second experiment and thereafter. Photographs 1 and 2 show electron photomicrographs (replica $\times 3000$ ) of the surface of the annealed specimens and the results of EPMA analysis, respectively. As shown in Photo. 1 , the annealed pure-iron-base sheets (Photos. 1 (a) and (b)) indicated smooth surfaces which differed little between 2 oxygen contents. On the other hand, fine precipitates were observed on the surfaces of the annealed SP-type sheets (Photos. 1 (c) and (d)), which differed with the oxygen contents. That is to say, relatively large precipitates were found in the grain boundaries of the specimen with a low oxygen content, while fine precipitates were found in the grains of the specimen with a high oxygen content.

Then, as shown in Photo. 2, concentration of manganese was observed on the surfaces of the SP-base type sheets. The conditions of occurrence also differed with the oxygen contents. That is, the concentration was uniform on the surface of the lowoxygen specimen, and locally segregated on that of the high-oxygen specimen. These fine precipitates and segregated manganese were not observed on the surface of the unannealed cold rolled steel sheets. Thus the precipitates were estimated as such substances as $\mathrm{MnO}$ and $\mathrm{MnS}$ precipitating during the

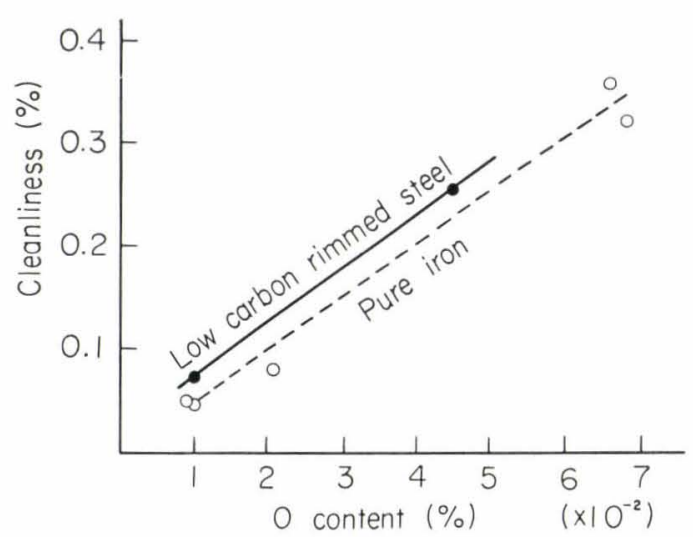

Fig. 3. Relation between oxygen content and cleanliness

annealing process. It seems that the conditions in which these precipitates are present in the pure-ironbase and SP-base steel sheets correspond to the difference in the characteristics of rust formed on the sheets.

\section{Relationship between the Balance of Manganese, Sulfur and Oxygen, and Surface Reactivity}

Considering the results described in III.1., 12 types of annealed steel sheets containing different amounts of manganese, sulfur and oxygen (but equal in copper content) were prepared, and their surface reactivities were investigated.

\section{Manganese, Sulfur and Oxygen Contents and Rusting}

Figure 4 illustrates the effects of the three elements on rusting. As is evident from this figure, individual addition of manganese, sulfur and oxygen to the pureiron-base steel exhibits little influence on the rust formation. When 2 elements, that is, manganese plus sulfur and manganese plus oxygen, are added, together, the influence appears. Then, when all of the three elements, i.e., manganese, sulfur and oxygen, are added at the same time, maximum rust formation occurs. It has been found that $\mathrm{FeO}$ or $\mathrm{FeS}$, at least when present alone, hardly affects the rust formation, while $\mathrm{MnS}$ or $\mathrm{MnO}$ makes the steel liable to rust. In Figs. 5 and 6, the amount of precipitated manganese $(55 / 16 \mathrm{O}+55 / 32 \mathrm{~S})$ and the amount of manganese in solid solution (total manganese minus precipitated manganese), which were calculated based on the manganese, sulfur and oxygen contents of the specimens, are plotted against the amount of rust formed, respectively. As understood from Fig. 5, the amount of precipitated manganese (i.e., $\mathrm{MnS}$ and $\mathrm{MnO}$ ) was found to have a very close relation with the formation of rust, with the steels becoming markedly liable to rust especially when the amount of precipitated manganese exceeds $0.1 \%$. On the other hand, the amount of rust formed indicated no direct relation with the amount of manganese in solid solution, as plotted in Fig. 6, but varied with the amounts of total manganese. In the steels containing a greater amount of manganese in solid solution, the formation of rust appears to be inhibited. But this is due to the fact that the precipitated manganese 
Photo. 1.

Replica of surfaces of steels containing various $\mathrm{MnS}$ and $\mathrm{O}$ (Annealed at $700^{\circ} \mathrm{C}$ for $2 \mathrm{hr})(\times 3000)$

(a)

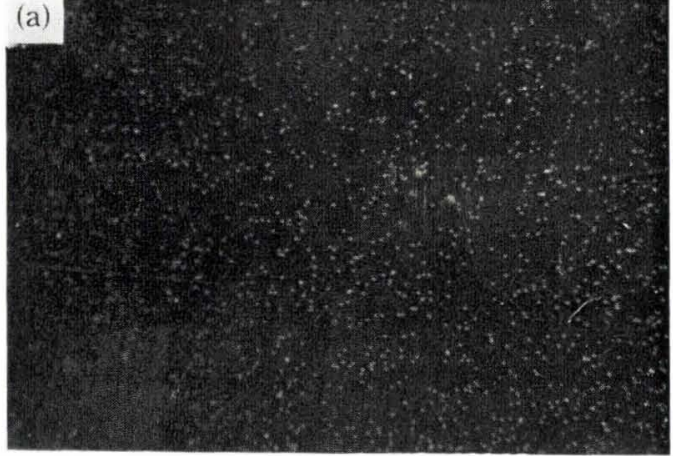

(c)

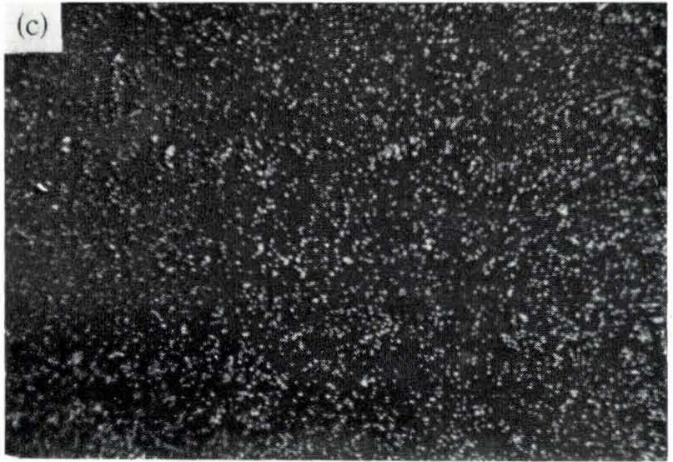

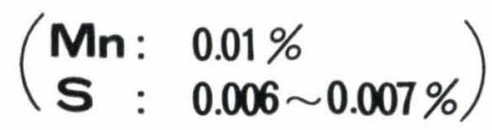

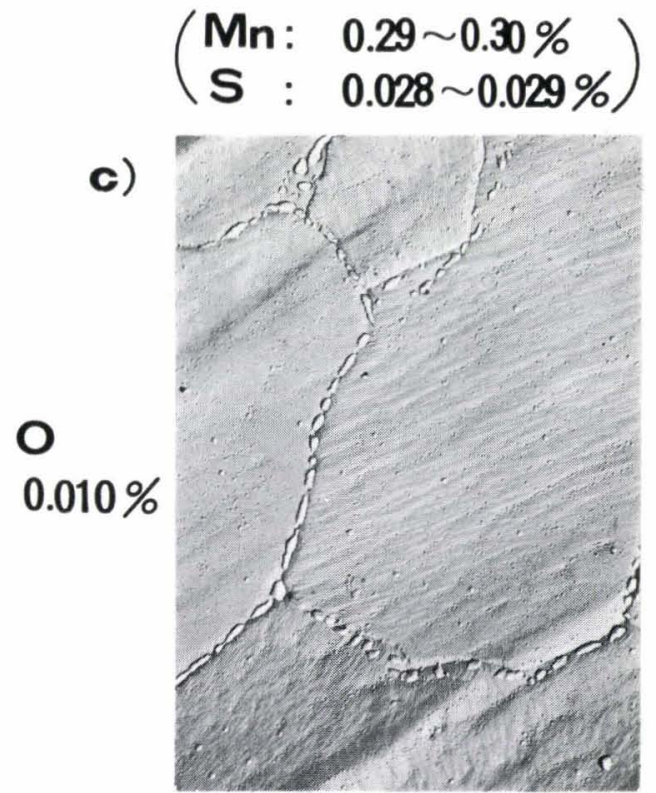

b)
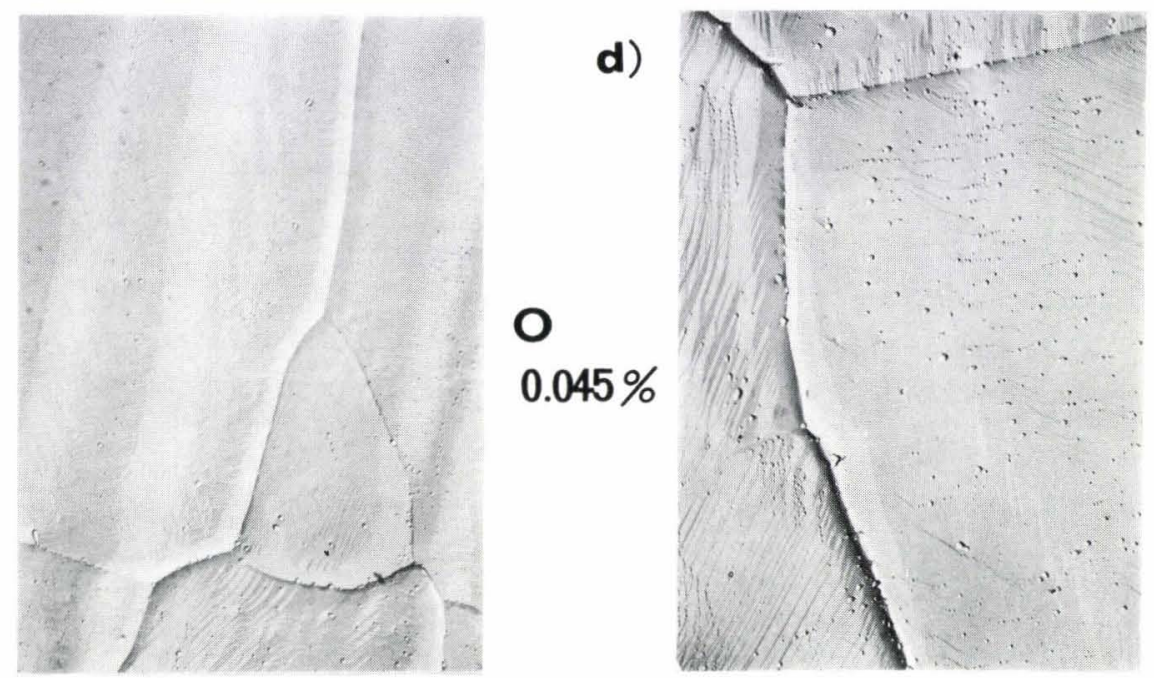

$\times 3000$ (b)
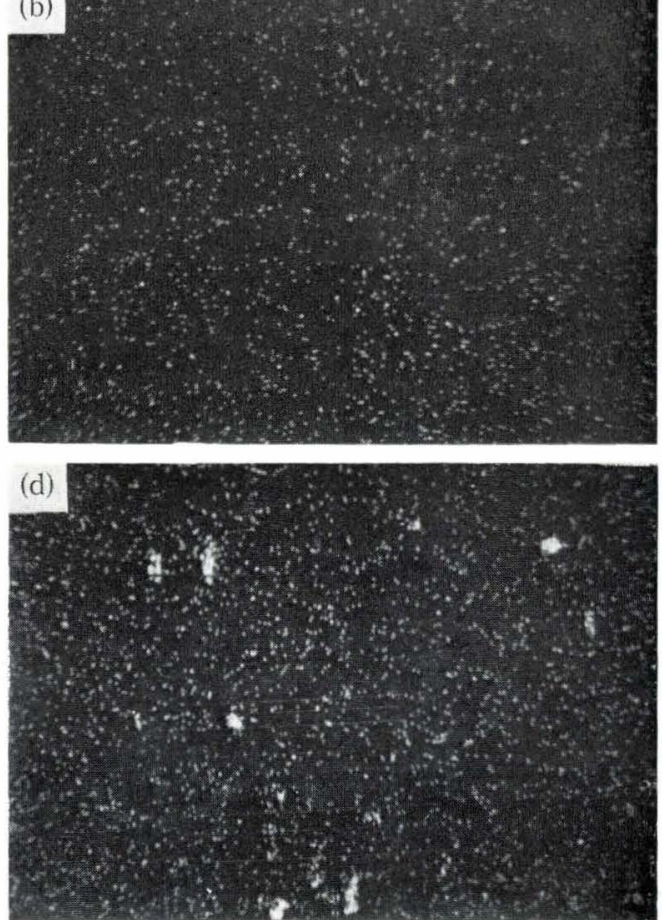

(a), (b): $\mathrm{Mn}=0.010 \%$,

$\mathrm{S}=0.006 \sim 0.007 \%$

(c), (d): $\mathrm{Mn}=0.29 \sim 0.30 \%$, $\mathrm{S}=0.020 \sim 0.029^{\circ} \%$

(a), (c): $\mathrm{O}=0.010 \%$

(b), (d): $\mathrm{O}=0.45 \%$

Photo. 2.

Scanning images of characteristic X-ray from manganese $(\times 260)$ 

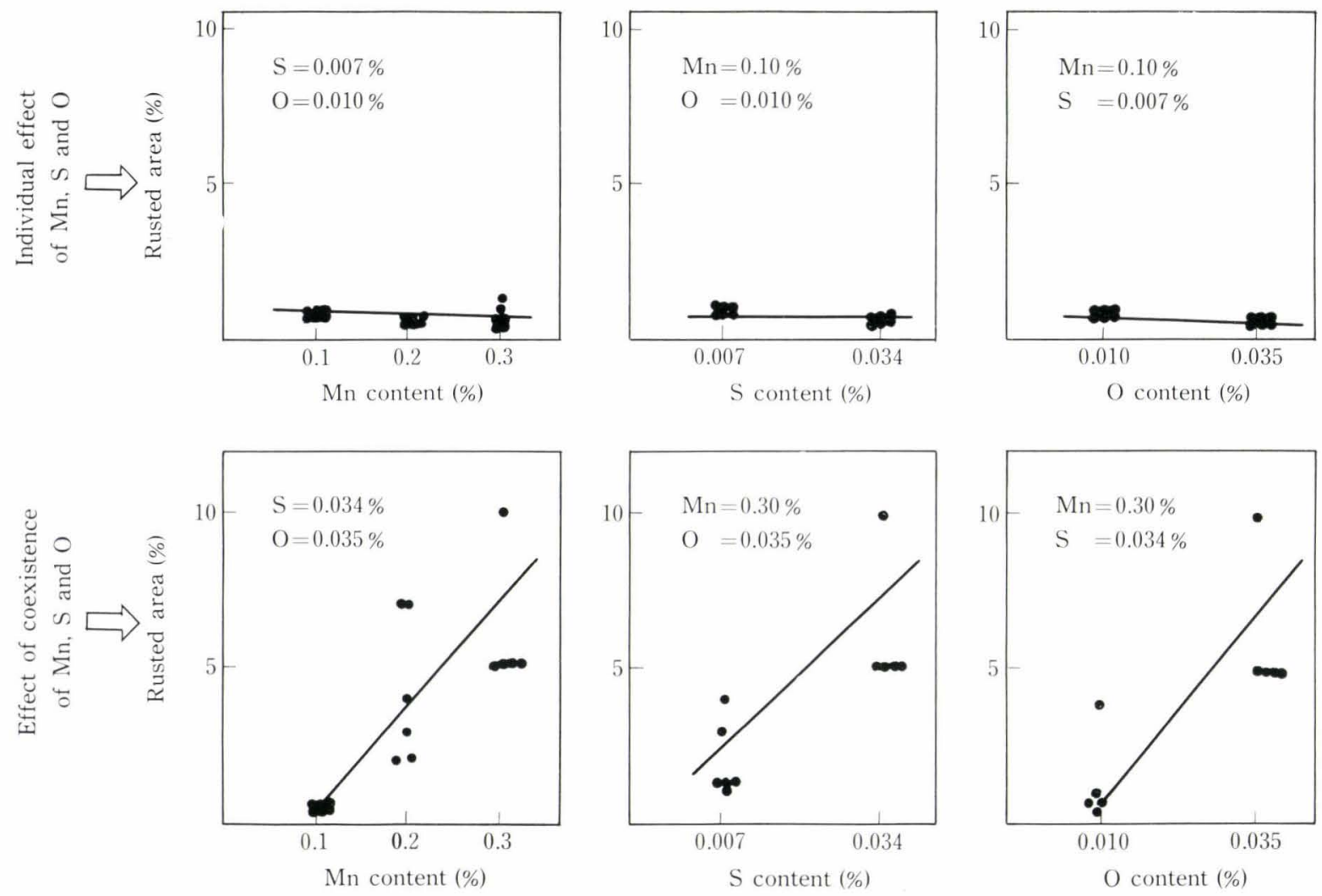

Fig. 4. Relation between manganese, sulfur and oxygen contents and rusting

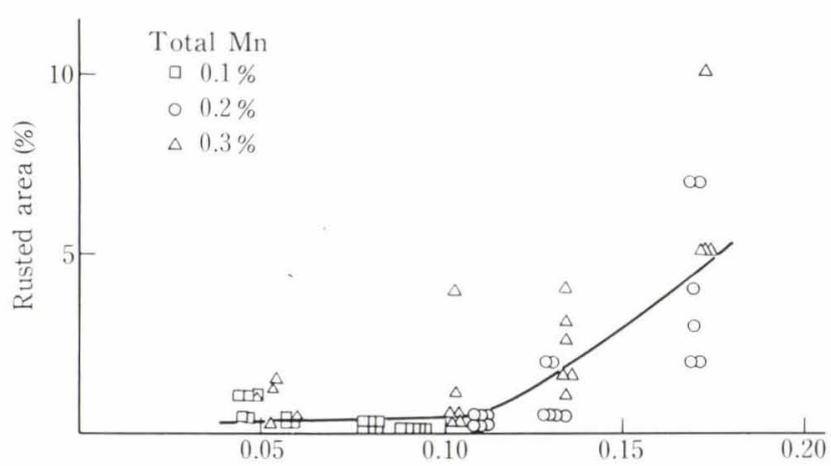

Concentration of precipitated $\mathrm{Mn}(\mathrm{MnS}+\mathrm{MnO})(\%)$

Fig. 5. Effect of precipitated manganese on rusting

decreases with an increase in the manganese in solid solution, if the amount of total manganese is kept constant.

\section{Formation of Phosphate Film}

Corrosion resistance of the specimens painted after phosphate treatment, is plotted against the amount of precipitated manganese in Fig. 7, and against the amount of manganese in solid solution in Fig. 8. Figure 7 shows that corrosion resistance increases with an increase in the precipitated manganese, which in turn indicates that the reactivity necessary for the formation of phosphate film increases with the increase in the precipitated manganese. Different from the case of rust, however, corrosion resistance is not controlled solely by the amount of precipitated manganese, but partly by the amount of total manganese (that is, the amount of manganese in solid solution). If the amount of precipitated manganese is kept con-

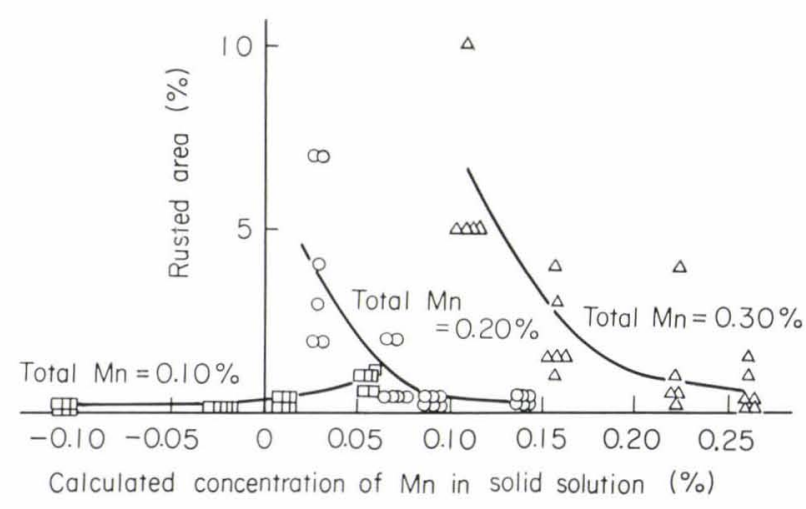

Fig. 6. Relation between manganese in solid solution and rusting

stant, the greater the amount of manganese in solid solution, and the higher the corrosion resistance (small blister). This means that the reactions of the rusting and of the phosphating proceed by different mechanisms.

\section{Influence of Sulfur Precipitating Behavior on Rusting}

The two types of hot-rolled SP-base steels, containing different amounts of sulfur as shown in Table 3, were subjected to different heat treatments so as to change the precipitating condition of sulfur. Then, the sheets as cold-rolled and annealed were checked for rust formation. Brown's data ${ }^{9)}$ concerning the $\mathrm{Fe}-\mathrm{Mn}-\mathrm{S}$ equilibrium diagram was employed in calculating the amounts of precipitated sulfur and sulfur in solid solution expected of these specimens. The values obtained are shown in Table 5 . 


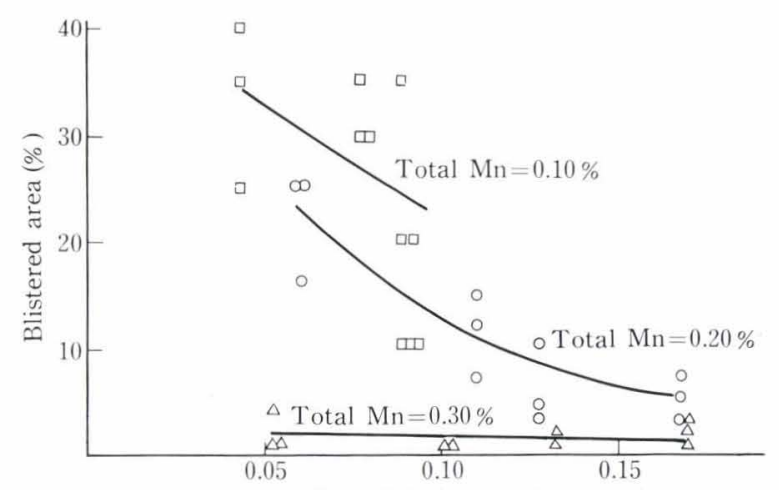

Concentration of precipitated $\mathrm{Mn}(\mathrm{MnS}+\mathrm{MnO})(\%)$

Fig. 7. Relation between precipitated manganese and corrosion resistance of phosphatized

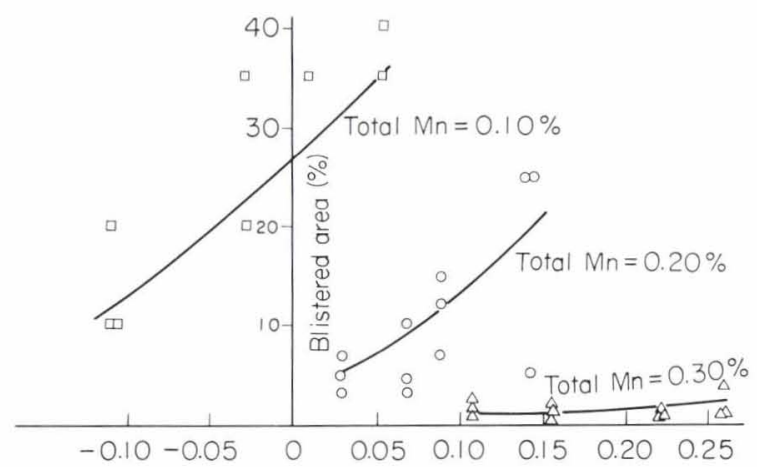

Calculated concentration of $\mathrm{Mn}$ in solid solution (\%)

Fig. 8. Relation between manganese in solid solution and corrosion resistance of phosphatized sheets

The relationships between the amounts of rust formed and sulfur precipitated on the cold-rolled sheets are shown in Fig. 9, and those on the annealed sheets in Fig. 10. In Figs. 9 and 10, different from the case of Fig. 5, the amount of rust formed depends not only on the amount of sulfur precipitated, but also on the manufacturing conditions.

As shown in Fig. 9, the slowly cooled specimens (water-cooled from $800^{\circ} \mathrm{C}$ ) rusted more readily than the quickly cooled ones (water-cooled from $1200^{\circ} \mathrm{C}$ ). This is accounted for by the fact that the sulfur in solid solution can well precipitate out in the form of sulfides (i.e., FeS and $\mathrm{MnS}$ ) while the steel is being cooled slowly. The steel that is higher in total sulfur content (SP-B) precipitated out more sulfur but was less liable to rust than the steel with lower sulfur content (SP-A). It may be because of the fact that composition of the precipitated sulfide (i.e., chemical activity of the sulfide) differs with the type of steel. This matter will be given further consideration later.

Figure 10 shows the relationship between the rusted area $(\%)$ and the total sulfur content of the same specimens shown in Fig. 9 after annealing at $700^{\circ} \mathrm{C}$. It is considered from this result that all the sulfur in solid solution reprecipitated as $\mathrm{MnS}$ when the coldrolled sheet is annealed. (According to Brown, the sulfur in solid solution at $700^{\circ} \mathrm{C}$ is not more than $0.001 \%$.) Also, the precipitated sulfur (generally in the form of $(\mathrm{Mn} \cdot \mathrm{Fe}) \mathrm{S})$ in the cold-rolled sheet
Table 5. Concentration of sulfur in solid solution and precipitate $(\%)$

\begin{tabular}{l|cr|cr}
\hline & \multicolumn{2}{|c|}{$\begin{array}{c}\text { Rapid cooling } \\
\text { quenched from } \\
1200^{\circ} \mathrm{C}\end{array}$} & \multicolumn{2}{c}{$\begin{array}{c}\text { Slow cooling } \\
\text { quenched from } \\
800^{\circ} \mathrm{C}\end{array}$} \\
\hline & $\begin{array}{c}\text { solid } \\
\text { solution }\end{array}$ & $\begin{array}{c}\text { S pre- } \\
\text { cipitate }\end{array}$ & $\begin{array}{c}\text { solid } \\
\text { solution }\end{array}$ & $\begin{array}{c}\text { S pre- } \\
\text { cipitate }\end{array}$ \\
\hline SP-A (high S) & 0.020 & 0.006 & 0 & 0.026 \\
SP-B (low S) & 0.007 & 0.008 & 0 & 0.015
\end{tabular}

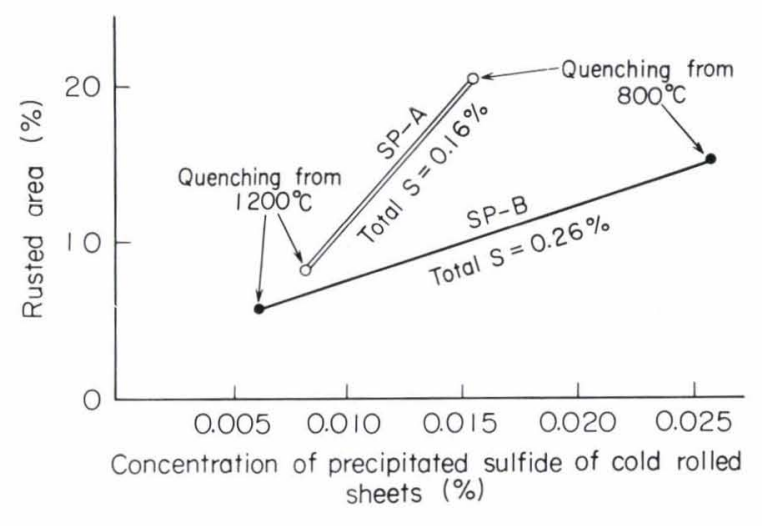

Fig. 9. Relation between precipitated sulfide and rusting on cold-rolled sheets

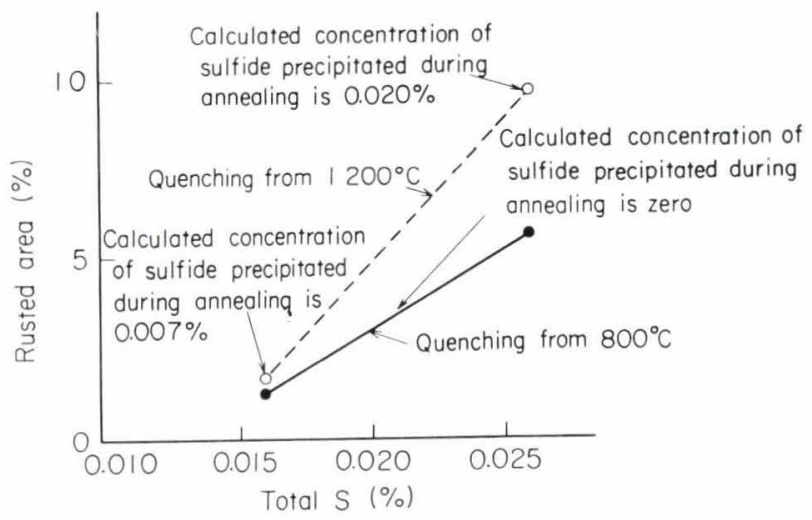

Fig. 10. Effect of sulfide precipitated during annealing on rusting

changes into MnS on being annealed. Therefore, all the precipitated sulfide may be considered to consist of MnS. But, as shown in Fig. 10, the effect of heat treatment before cold-rolling still remains, and slowly cooled steel (which has little sulfur in solid solution to reprecipitate on being annealed at $700^{\circ} \mathrm{C}$ ) is less liable to rust, in contrast with the as-rolled steel. This may be understood by considering that the $\mathrm{MnS}$ reprecipitated as a result of annealing has a very high activity. The results of the EPMA analysis of the surface of the annealed steels S1 and S2 in Table 4 are shown in Photo. 3. These photomicrographs show that the $\mathrm{MnS}$ reprecipitated by annealing forms very fine deposits on the surface of the steels with high manganese and sulfur contents.

\section{Effect of Carbon}

Figure 11 shows the amounts of rust formed on the surface of an ultra-low-carbon steel sheet (C>0.005\%) 

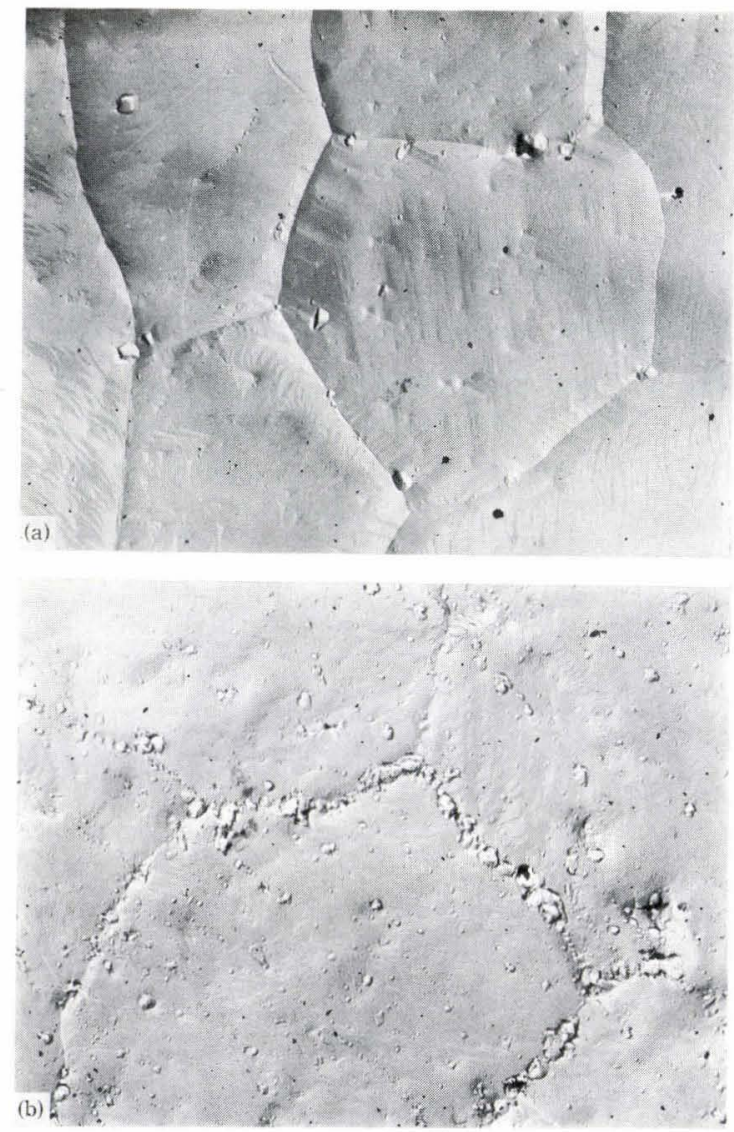

(a) $\mathrm{Mn}=0.10 \%, \quad \mathrm{~S}=0.005 \%$

(b) $\mathrm{Mn}=0.33 \%, \quad \mathrm{~S}=0.013 \%$

Photo. 3. Negative replica of surfaces of SPCC annealed at the laboratory $(\times 6000)(\times 1 / 2)$

and a low-carbon steel sheet $(\mathrm{C}=0.005 \%)$. As seen from this figure, the presence of not only sulfur but also carbon accelerates the formation of rust. Because most of the carbon in these specimens precipitates as cementite, this acceleration is considered to be the effect of cementite.

\section{Discussion}

Sulfide inclusions have a remarkable influence on the surface reactivity of low-carbon steel sheets. Among the sulfides, MnS has the highest surface activity, while FeS has the lowest. It is therefore estimated that the surface activities of steels differ with their compositions (the ratios of $\mathrm{Fe}$ to $\mathrm{Mn}$ in ( $\mathrm{Mn}$. $\mathrm{Fe}) \mathrm{S}$ ), and that the sulfides reprecipitated by annealing have great activities. Oxide inclusions ( $\mathrm{MnO}$ ) also activate the surface of steel. The relationships of these factors with the surface activity will be discussed hereafter.

\section{Compositions of Sulfide Inclusions and Surface Activity}

It has been noted that FeS exerts greater influence than MnS on the type of corrosion which generates hydrogen. ${ }^{10)}$ It has been confirmed that the materials which are liable to cause hydrogen embrittlement contain more FeS than those which are not. ${ }^{11}$ More particularly; it can be noted that FeS, with good electric conductivity, accelerates corrosion by forming

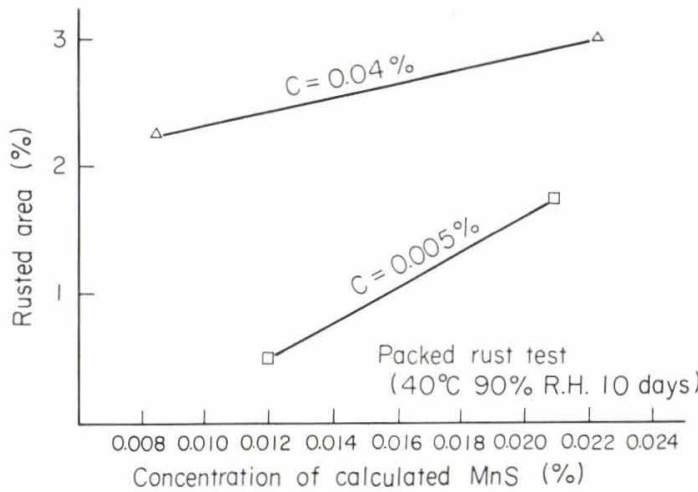

Fig. 11. Effect of $\mathrm{MnS}$ and $\mathrm{C}$ on rusting

galvanic cells with base iron, whereas $\mathrm{MnS}$ with much lower electric conductivity than that of $\mathrm{FeS}$ (FeS: $15 \Omega^{-1} \mathrm{~cm}^{-1}$ (parallel to carbon axis) and $430 \Omega^{-1}$ $\mathrm{cm}^{-1}$ (perpendicular to carbon axis), $\mathrm{MnS}: 0.1 \Omega^{-1}$ $\left.\mathrm{cm}^{-1}\right) .{ }^{11}$ In contrast to this, $\mathrm{MnS}$ shows greater influence on rusting than FeS. This fact suggests that the reaction to form rust does not occur in the cause of galvanic cell between the sulfides and base iron. $\mathrm{MnS}$ is more soluble in water than $\mathrm{FeS}$, and produces $\mathrm{H}_{2} \mathrm{~S}$ by the following reaction:

$$
\begin{aligned}
& \mathrm{MnS}+2 \mathrm{H}_{2} \mathrm{O} \rightleftharpoons \mathrm{Mn}(\mathrm{OH})_{2}+\mathrm{H}_{2} \mathrm{~S} \\
& \left(\rightleftharpoons \mathrm{H}^{+}+\mathrm{SH}^{-} \rightleftharpoons 2 \mathrm{H}^{+}+\mathrm{S}^{2-}\right)
\end{aligned}
$$

According to Havenhand, $\mathrm{H}_{2} \mathrm{~S}$ in solution makes the corrosion potential of steel less noble, and at the same time increases the corrosion rate. According to Wranglen, MnS in steel shifts the corrosion potential toward the less noble direction. The explanation offered to these facts is that sulfide contributes to the anode reaction and $\mathrm{H}_{2} \mathrm{~S}$ or $\mathrm{S}^{2-}$ (or $\mathrm{SH}^{-}$) adsorbed to the anodic area acts like a depolarizer (Havenhand called this an anodic stimulator). However, in such type of corrosion as the formation of pinpoint rusting (and also pitting corrosion) that occurs under a condition where the anodic and cathodic areas are separated from each other, it seems more reasonable to consider that $\mathrm{MnS}$ in steel increases corrosion through the increase in the anodic defective area and the decrease in ohmic resistance (between pits and surrounding oxide film) caused by the formation of $\mathrm{H}_{2} \mathrm{~S}$. For example, one of the authors, who investigated the action of $\mathrm{MnS}$ on the auto-reductive behavior of the oxide film in neutral solution, presumed that $\mathrm{MnS}$ forms anodic defect in the oxide film which becomes the origin of rust. ${ }^{12)}$ Also, Okada and Shimada confirmed by microscopic observations of hot-rolled steel sheet with high manganese and sulfur contents that rusting stars with the dissolution of sulfides. ${ }^{13}$ )

In ordinary low-carbon steels, the ratio of manganese to sulfur is usually 10 or more to 1 . In such steels, all the sulfides is assumed to be the form of $\mathrm{MnS}$ at room temperature, in a thermodynamically equilibrium state. However, the sulfides in the hotrolled or cold-rolled steel before annealing do not usually reach such equilibrium, and therefore are formed as $(\mathrm{Mn} \cdot \mathrm{Fe}) \mathrm{S}$ in which some $\mathrm{FeS}$ is present in the form 
of solid solution. ${ }^{11)}$ The ratio of $\mathrm{FeS}$ in $(\mathrm{Mn} \cdot \mathrm{Fe}) \mathrm{S}$ increases as the cooling rate after hot-rolling increases, and also as the ratio of manganese to sulfur decreases. ${ }^{11)}$ It is further evident from Brown's data that FeS content increases with rise in hot-rolling temperature. There are many papers as to the ratio of $\mathrm{FeS}$ in the total sulfides; Kiessling reported the presence of as much as $58 \%$ of $\mathrm{FeS}$ in the sulfides contained in a steel containing $0.14 \%$ manganese and $0.015 \%$ sulfur, ${ }^{14)}$ and Hoff reported that $\mathrm{FeS}$ accounted for 14 to $43 \%$ of the sulfides contained in sulfur bearing free cutting steels whose ratio of manganese to sulfur ranged between 2.5 and 5 to $1 .{ }^{15}$ )

From the results of the rusting test performed on the cold-rolled sheets cooled at different rates after hot-rolling, it can readily be presumed that less FeS is contained in the sulfides precipitated in the steel slowly cooled to $800^{\circ} \mathrm{C}$ than in the sulfides in the steel rapidly cooled from $1200^{\circ} \mathrm{C}$, and that the ratio of $\mathrm{FeS}$ is high in the high-sulfur steel owing to the drop of the ratio of manganese to sulfur (high-sulfur steel: $\mathrm{Mn}: \mathrm{S}=11: 1$, low-sulfur steel: $\mathrm{Mn}: \mathrm{S}=18: 1)$.

\section{Precipitating Condition of $\mathrm{MnS}$ and Action of $\mathrm{MnO}$}

It appears from Fig. 4 that $\mathrm{MnO}$ has a function of accelerating rusting, but it can hardly be considered that $\mathrm{MnO}$ itself increases the anodic activity as $\mathrm{MnS}$. Rather, $\mathrm{MnO}$ is supposed to exert indirect on rusting by affecting the precipitating condition of $\mathrm{MnS}$. For instance, Witmer found as a result of his experiments with a steel containing $0.04 \%$ carbon, $0.31 \%$ manganese, $0.02 \%$ sulfur and $0.042 \%$ oxygen that the formation of $\mathrm{MnO}$ in the hot-rolled steel resulted in decreasing the amount of $\mathrm{Mn}$ in solid solution in the neighboring of $\mathrm{MnO}$, which in turn increased the amount of sulfur in solid solution precipitating as fine-grained sulfides during annealing after coldrolling. ${ }^{16)}$ Takechi and Masui showed that a large quantity of $\mathrm{MnS}$ (which was proved to be $\beta$-MnS by electron diffraction) precipitated out in the steel with high-oxygen content $(0.045 \%$ oxygen), while little $\mathrm{MnS}$ precipitated in the steel with low-oxygen content $\left(0.010 \%\right.$ oxygen). ${ }^{17)}$ Accordingly, it is thought that an increase in $\mathrm{MnO}$ concentration is accompanied by a decrease in the amount of manganese in solution (total Mn-55/160), which determines the precipitation equilibrium relation between manganese and sulfur. Therefore the solubility limit of sulfur in austenite can be increased (or, in other words, increases the amount of the solid solution of sulfur in the steel as hot-rolled), and consequently, precipitates plenty of $\mathrm{MnS}$ with high surface activity during subsequent annealing.

\section{Mechanisms of Rusting and Phosphate Film Formation and Action of Steel Components}

The initial rusting and the formation of phosphate film are basically electrochemical corrosions. The local anode reactions of these electrochemical reactions consist of the dissolution of iron $\left(\mathrm{Fe}=\mathrm{Fe}^{2+}+2 e\right)$, but their local cathode reactions differ from each other. In the case of rusting, it consists of oxygen discharge $\left(\mathrm{O}_{2}+2 \mathrm{H}_{2} \mathrm{O}+4 e=4 \mathrm{OH}^{-}\right)$, while, in the case of forming phosphate film, it consists of the generation of hydrogen $\left(\left(2 \mathrm{H}^{+}+2 e\right)=\mathrm{H}_{2}\right)$. It is known that when steel is covered with a thin film of water, diffusion of oxygen takes place easily, therefore the diffusion does not become a rate-determining process, and the formation of initial rust becomes an anodic control, that is, the dissolution of iron is the rate-determining step. ${ }^{6}$ ) In contrast, the formation of phosphate film is said to be a cathodic control (the generation of hydrogen is the rate-determining step). ${ }^{18)}$ In the reaction to form phosphate film, crystals of phosphate precipitate around the local cathode (that is, $\mathrm{Zn}_{3}\left(\mathrm{PO}_{4}\right)_{2}$ precipitates as a result of a rise in $\mathrm{pH}$ in the cathode area). In this connection, Machu pointed out that the grain boundaries and non-metallic inclusions in steel would then serve as the local cathode. ${ }^{19)}$ However, as mentioned previously, MnS does not play a role as the local cathode, but rather as a depolarizer for the anodic reaction. It is consequently presumed that the phosphating reaction is not a cathode control but a mixed control from the fact that $\mathrm{MnS}$ also accelerates the formation of phosphate film.

$\mathrm{Fe}_{3} \mathrm{C}$ accelerates the formation of phosphate film as $\mathrm{MnS}$ does ${ }^{7)}$ but, different from $\mathrm{MnS}, \mathrm{Fe}_{3} \mathrm{C}$ is known to act as the local cathode in the corrosion reaction in acid. ${ }^{4}$ Accordingly, $\mathrm{Fe}_{3} \mathrm{C}$ is thought to accelerate the cathodic reaction in phosphating reaction. In the rusting reaction, however, $\mathrm{Fe}_{3} \mathrm{C}$ is considered to stimulate the formation of rust by increasing the area of cracks or defects (anodic defects) in the oxide film.

The difference between the rusting and phosphating reactions lies also in the fact that the former is hardly affected by manganese in solid solution, while the latter is heavily influenced. On the assumption that the former is anodic control and the latter is mixed control, manganese in solid solution is considered to accelerate the formation of phosphate film by stimulating the local cathodic reaction in mixed control. Figure 12 depicts Evans' polarization diagrams which show the effects of the above-mentioned components on the rusting and phosphating reactions, respectively.

\section{Conclusion}

The present study of the effects of steel components on the surface reactivities (the rusting and phosphating reactions) of steel sheets has revealed the following facts:

(1) Sulfide inclusions, especially $\mathrm{MnS}$, have the greatest influence on the surface reactivities of steel sheets. MnS makes the steel liable to rust, but at the same time enhances the phosphating reactivities (which leads to an improvement in corrosion resistance after painting).

(2) Not only the concentration of the sulfides, but also their composition (the ratio between $\mathrm{MnS}$ and $\mathrm{FeS}$ ) and precipitating condition (the size of precipitate's particles) have an influence on the surface reactivities. Namely, the higher the percentage of $\mathrm{MnS}$ in the total sulfides and the finer the crystals 

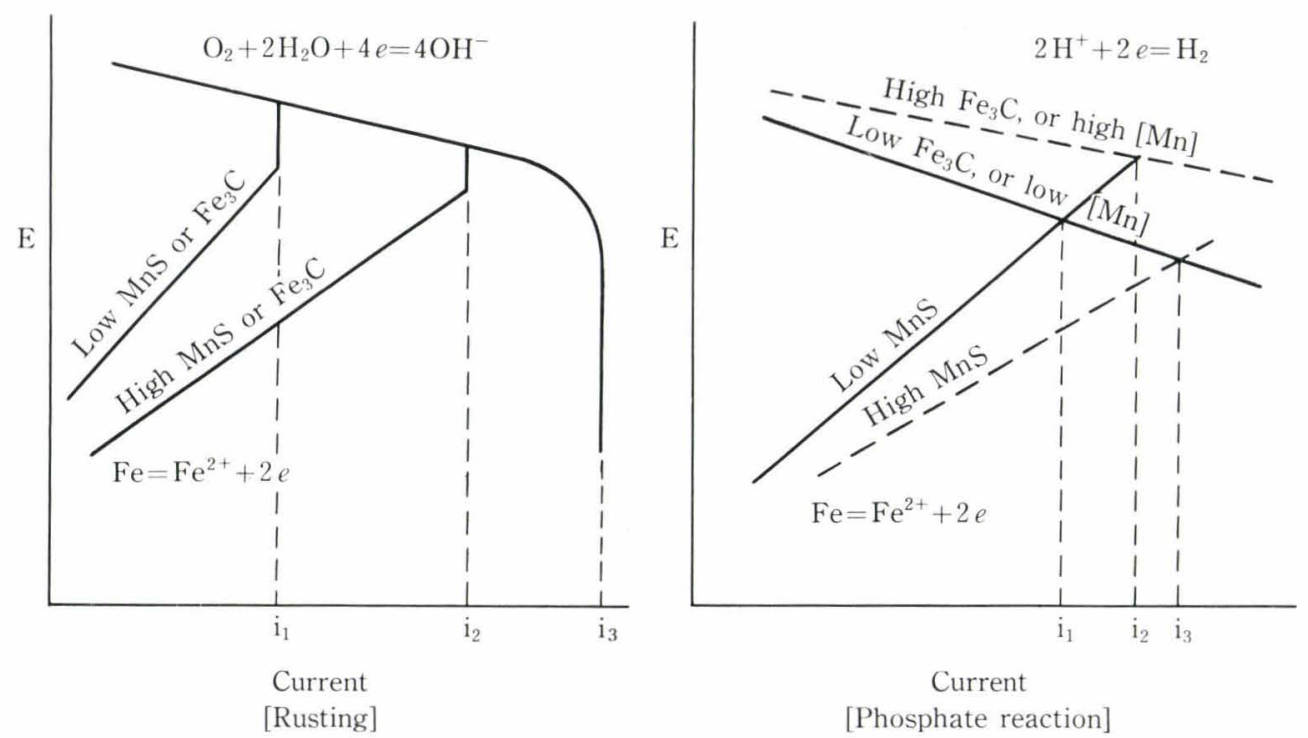

Fig. 12. Evan's polarization diagram, showing the effects of components on rusting and phosphating reactions

of $\mathrm{MnS}$ reprecipitating from the solid solution of sulfur as a result of annealing, the greater will be the surface reactivities.

(3) $\mathrm{MnO}$ increases the rusted area, which, however, is not considered as its direct action, but as its apparent effect which can in reality be ascribable to the increased precipitation of fine-grained $\mathrm{MnS}$ during annealing in the steel with high $\mathrm{MnO}$ content.

(4) $\mathrm{Fe}_{3} \mathrm{C}$ accelerates the formation of rust, as does $\mathrm{MnS}$. This seems to be due to the fact that $\mathrm{Fe}_{3} \mathrm{C}$ increases anodic defects in the oxide film on the surface of steel. On the other hand, manganese in solid solution has little influence on rusting, but accelerates the phosphating reaction.

(5) It is considered that the initial rust forming reaction is an anodic control, while that to form phosphate film is a mixed control.

By stimulating the local anodic reaction, $\mathrm{MnS}$ affects both the rusting and phosphating reactions. $\mathrm{Fe}_{3} \mathrm{C}$ and manganese in solid solution accelerates the formation of phosphate film by depolarizing the local cathodic reaction.

\section{REFERENCES}

1) P. B. Hoar and G. Havenhand: JISI, 133 (1936), 239.

2) E. Williams and M. E. Komp: Corrosion, 21 (1965) 9.

3) H. Cleary and N. D. Greene: Corros. Sci., 9 (1969), 3.
4) Z.A. Foroulis and H. H. Uhlig: J. Electrochem. Soc., 111 (1964), 522; 112 (1965), 1180.

5) C. P. Larrabee and S. K. Coburn: 1st Inten. Congr. on Metallic Corrosion, Butterworth, London, (1961), 276.

6) N. D. Tomashov: Theory of Corrosion and Protection of Metals, MacMillan, New York, (1966), 367.

7) S. Shimada and S. Maeda: Tetsu-to-Hagané, 59 (1973), 1983; Trans. ISIJ, 15 (1975) 95.

8) H. Asano and S. Maeda: Presented at 46th Meeting of The Metal Finishing Society of Japan, (1972), 140.

9) J. R. Brown: JISI, 205 (1967), 154.

10) J. W. Coff: JISI, 83 (1911), 170.

11) G. Wranglen: Corros. Sci., 9 (1969), 585.

12) H. Asano and S. Maeda: Corrosion Engineering (Boshoku Gijutsu), 23 (1974), 239.

13) H. Okada and H. Shimada: Tetsu-to-Hagané, 60 (1974), 540 .

14) P. Kiessling and N. Lange: Nonmetallic Inclusion in Steel, II, ISI Publication, No. 100, (1966), 97.

15) H. Hoff, G von der Duck and H. Lessig: Stahl u. Eisen, 77 (1957), 1210.

16) D. A. Witmer and R. M. Willison: Met. Trans., 2 (1951), 591.

17) H. Takechi and H. Masui: Tetsu-to-Hagané, 59 (1973), 1273.

18) R. Shirakawa, S. Takeda, T. Umeda and T. Okabe: Bull. Chem. Soc. Japan, 44 (1971), 1007.

19) W. Machu: Korrosion u. Metallshutz, 17 (1941), 157; 18 (1942), 89; and 20 (1944), 1. 